Supplement of The Cryosphere, 14, 3907-3916, 2020

https://doi.org/10.5194/tc-14-3907-2020-supplement

(c) Author(s) 2020. This work is distributed under

the Creative Commons Attribution 4.0 License.

(c) (1)

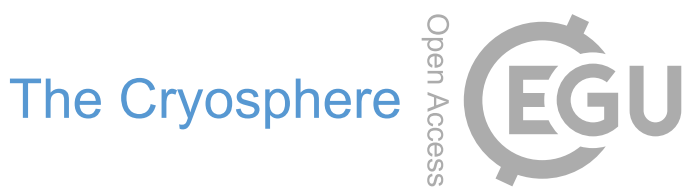

Supplement of

\title{
Permafrost thawing exhibits a greater influence on bacterial richness and community structure than permafrost age in Arctic permafrost soils
}

Mukan Ji et al.

Correspondence to: Weidong Kong (wdkong@itpcas.ac.cn)

The copyright of individual parts of the supplement might differ from the CC BY 4.0 License. 
Table S1 The individual and interactive effects of permafrost thawing status and age on the soil bacterial richness.

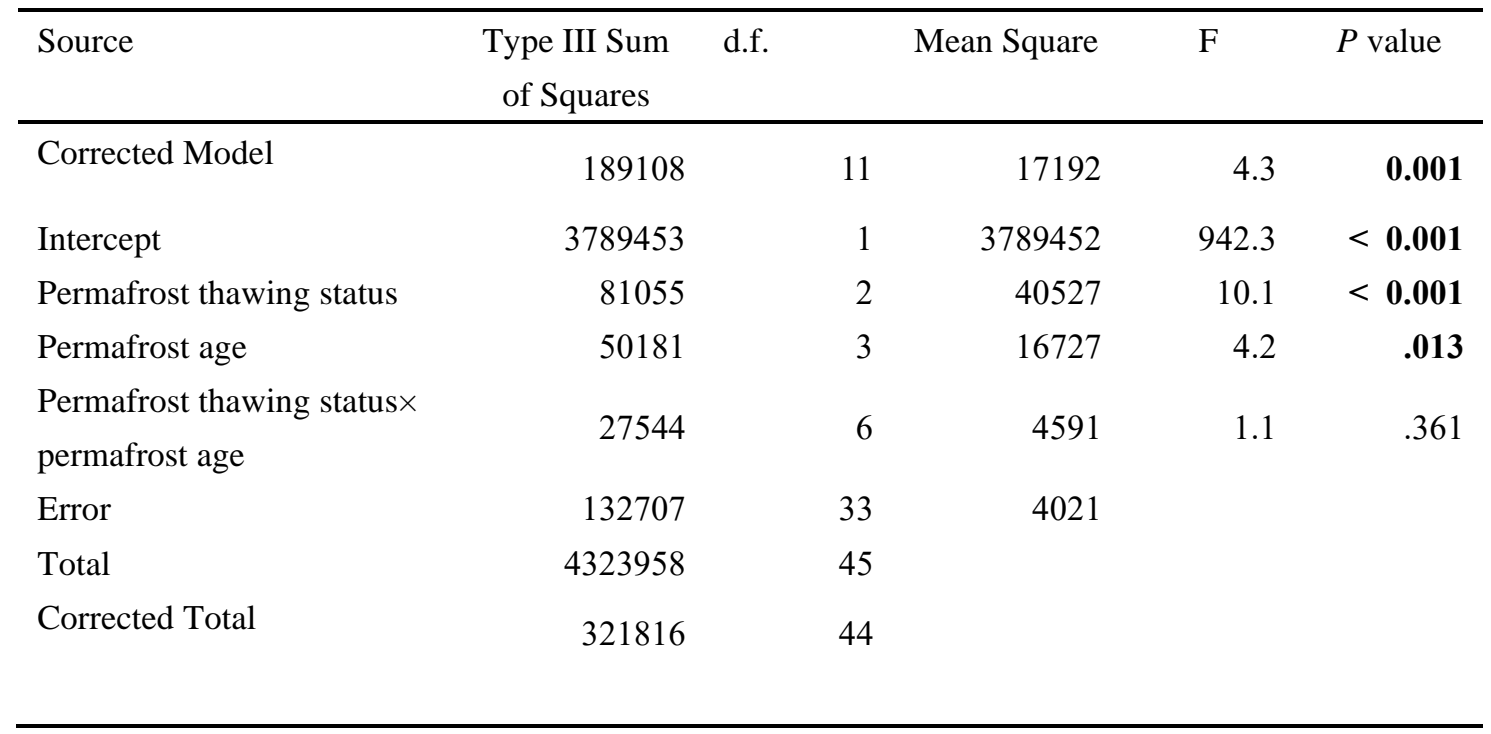

Analysis is based on two-way ANOVA, significance at $P<0.05$ is in bold. 
Table S2 The bacterial richness by permafrost thawing status.

\begin{tabular}{lcccc} 
& Mean \pm S.D. & Active & Transition & Permanently \\
& & & & frozen \\
\hline Active & $354 \pm 17$ & - & - & - \\
Transition & $287 \pm 16$ & $\mathbf{0 . 0 1 1}$ & - & - \\
& & & & - \\
Frozen & $248 \pm 18$ & $<\mathbf{0 . 0 0 1}$ & 0.221 & \\
\hline
\end{tabular}

S.D. standard deviation, significance is based on the Tukey's post hoc test, statistically significant differences (at $P<0.05$ level) are in bold. Active, transition, and frozen are different permafrost thawing status. 
Table S3 The bacterial richness by permafrost age.

\begin{tabular}{lccccc} 
& Mean \pm S.D. & Medium & Old & Ancient \\
& $(\%)$ & Young & . & & \\
\hline Young & $358 \pm 21$ & - & - & - & - \\
Medium & $268 \pm 19$ & $\mathbf{0 . 0 0 1}$ & - & - & - \\
Old & $272 \pm 18$ & $\mathbf{0 . 0 0 2}$ & 0.995 & - & - \\
Ancient & $287 \pm 18$ & $\mathbf{0 . 0 0 9}$ & 0.836 & 0.931 & \\
\hline
\end{tabular}

S.D. standard deviation, significance is based on the Tukey's post hoc tests, statistically significant differences (at $P<0.05$ level) are in bold. Young, medium, old, and ancient are permafrost soil ages. 
Table S4 The influence of permafrost thawing status on bacterial richness for soils of different ages.

\begin{tabular}{|c|c|c|c|c|c|c|}
\hline Soil age & Variation & $\begin{array}{l}\text { Sum of } \\
\text { Squares }\end{array}$ & d.f. & $\begin{array}{l}\text { Mean } \\
\text { Square }\end{array}$ & $\mathrm{F}$ & Sig. \\
\hline \multirow{3}{*}{ Young } & Between Groups & 70837 & 2 & 35418 & 41.644 & $<0.001$ \\
\hline & Within Groups & 5954 & 7 & 851 & & \\
\hline & Total & 76790 & 9 & & & \\
\hline \multirow{3}{*}{ Medium } & Between Groups & 5431 & 2 & 2715 & 0.898 & 0.445 \\
\hline & Within Groups & 24184 & 8 & 3023 & & \\
\hline & Total & 29615 & 10 & & & \\
\hline \multirow{3}{*}{ Old } & Between Groups & 9255 & 2 & 4628 & 0.798 & 0.480 \\
\hline & Within Groups & 52192 & 9 & 5799 & & \\
\hline & Total & 61447 & 11 & & & \\
\hline \multirow{3}{*}{ Ancient } & Between Groups & 15218 & 2 & 7609 & 1.359 & 0.305 \\
\hline & Within Groups & 50378 & 9 & 5598 & & \\
\hline & Total & 65596 & 11 & & & \\
\hline
\end{tabular}

Analysis is based on two-way ANOVA, significant influences (at $P<0.05$ level) are in bold. Young, medium, old, and ancient are permafrost soil ages. 
Table S5 The permafrost soil bacterial richness of the various permafrost layer in the young permafrost.

\begin{tabular}{lcccc}
\hline & Mean \pm S.D. (\%) & Active & Transition & Permanently \\
& & & & frozen \\
\hline Active & $471 \pm 37$ & - & - & - \\
Transition & $355 \pm 22$ & $\mathbf{0 . 0 0 2}$ & - & - \\
& $248 \pm 19$ & & $\mathbf{0 . 0 0 9}$ & - \\
Frozen & $\mathbf{< . 0 0 1}$ & & \\
\hline
\end{tabular}

Significance is based on the Tukey's post hoc test, statistically significant differences (at $P=0.05$ level) are in bold. Active, transition, and frozen are different permafrost thawing status. 
Table S6 The richness of bacteria phyla by permafrost thawing status (Proteobacteria at the Class level).

\begin{tabular}{|c|c|c|c|c|c|}
\hline & & Mean \pm S.D. & Active & Transition & Frozen \\
\hline \multirow[t]{3}{*}{ Firmicutes } & Active & $87 \pm 15$ & - & - & - \\
\hline & Transition & $47 \pm 15$ & 0.013 & - & - \\
\hline & Frozen & $49 \pm 8$ & 0.042 & 0.986 & - \\
\hline \multirow[t]{3}{*}{ Actinobacteria } & Active & $128 \pm 14$ & - & & \\
\hline & Transition & $106 \pm 10$ & 0.062 & 0.021 & \\
\hline & Frozen & $71 \pm 2$ & 0.002 & - & \\
\hline \multirow[t]{3}{*}{ Chloroflexi } & Active & $36 \pm 4$ & - & - & \\
\hline & Transition & $29 \pm 3$ & 0.095 & - & \\
\hline & Frozen & $16 \pm 6$ & 0.002 & 0.02 & \\
\hline \multirow[t]{3}{*}{ Alphaproteobacteria } & Active & $35 \pm 6$ & - & - & \\
\hline & Transition & $19 \pm 7$ & 0.016 & - & \\
\hline & Frozen & $16 \pm 4$ & 0.016 & 0.774 & \\
\hline \multirow[t]{3}{*}{ Deltaproteobacteria } & Active & $25 \pm 8$ & - & - & \\
\hline & Transition & $12 \pm 2$ & 0.028 & - & \\
\hline & Frozen & $11 \pm 2$ & 0.049 & 0.976 & \\
\hline
\end{tabular}

S.D. standard deviation, dominant phyla are defined with relative abundance $>1 \%$ across all samples. Significance is based on the Tukey's post hoc tests, statistically significant differences (at $P=0.05$ level) are in bold. S.D.: Standard deviation. Active, transition, and frozen are different permafrost thawing status. 
Table S7 The bacterial community structure differences identified among various permafrost thawing status and soil ages.

\begin{tabular}{ccccccc}
\hline Source & d.f. & SS & MS & Pseudo-F & P(perm) & $\begin{array}{c}\text { Unique } \\
\text { permutations }\end{array}$ \\
\hline $\begin{array}{c}\text { Soil age } \\
\text { Thawing status }\end{array}$ & 3 & 11653 & 3884.2 & 2.2297 & $\mathbf{0 . 0 0 1}$ & 999 \\
Thawing status $\times$ & 6 & 10890 & 5445.1 & 3.1258 & $\mathbf{0 . 0 0 1}$ & 998 \\
soil age & 6 & 2684.3 & 1.5409 & $\mathbf{0 . 0 0 1}$ & 994 \\
Residual & 33 & 57486 & 1742 & & & \\
Total & 44 & 97193 & & & & \\
\hline
\end{tabular}

Significance is based on PERMANOVA. 
Table S8 Bacterial community structure comparison among different thawing status by PERMANOVA post-hoc analysis.

\begin{tabular}{llll}
\hline & Active & Transition & Frozen \\
\hline Active & - & - & - \\
Transition & $\mathbf{0 . 0 0 6}$ & - & - \\
Frozen & $\mathbf{0 . 0 0 1}$ & $\mathbf{0 . 0 0 7}$ & - \\
\hline
\end{tabular}

P-values are shown, significant P-values are shown in bold. Active, transition, and frozen are different permafrost thawing status. 
Table S9 Bacterial community structure comparison among different permafrost ages by PERMANOVA post-hoc analysis.

\begin{tabular}{|l|l|l|l|l|}
\hline & Young & Medium & Old & Ancient \\
\hline Young & - & - & - & - \\
\hline Medium & $\mathbf{0 . 0 0 4}$ & - & - & - \\
\hline Old & $\mathbf{0 . 0 0 1}$ & 0.207 & - & - \\
\hline Ancient & $\mathbf{0 . 0 0 1}$ & $\mathbf{0 . 0 2 4}$ & 0.109 & - \\
\hline
\end{tabular}

P-values are shown, significant P-values are shown in bold. Young, medium, old, and ancient are permafrost soil ages. 
Table S10 The community structure differences of the soils with same age but at different permafrost thawing status.

\begin{tabular}{|c|c|c|c|c|c|c|c|}
\hline & Source & d.f. & SS & MS & Pseudo-F & $\mathrm{P}($ perm $)$ & $\begin{array}{c}\text { Unique } \\
\text { permutations }\end{array}$ \\
\hline \multirow[t]{3}{*}{ Young } & Thawing status & 2 & 9526 & 4763 & 3.45 & 0.002 & 749 \\
\hline & Residual & 7 & 9658 & 1380 & & & \\
\hline & Total & 9 & 19184 & & & & \\
\hline \multirow[t]{3}{*}{ Medium } & Thawing status & 2 & 6671 & 3336 & 1.66 & 0.027 & 926 \\
\hline & Residual & 8 & 16079 & 2010 & & & \\
\hline & Total & 10 & 22750 & & & & \\
\hline \multirow[t]{3}{*}{ Old } & Thawing status & 2 & 4807 & 2404 & 1.3 & 0.124 & 914 \\
\hline & Residual & 9 & 16699 & 1855 & & & \\
\hline & Total & 11 & 21506 & & & & \\
\hline \multirow[t]{3}{*}{ Ancient } & Thawing status & 2 & 5853 & 2927 & 1.75 & 0.016 & 914 \\
\hline & Residual & 9 & 15050 & 1672 & & & \\
\hline & Total & 11 & 20904 & & & & \\
\hline
\end{tabular}

Significance is based on PERMANOVA. Young, medium, old, and ancient are permafrost soil ages. 
Table S11 The community structure differences of the soils with same thawing status but at different permafrost ages.

\begin{tabular}{cccccccc}
\hline & Source & d.f. & SS & MS & Pseudo-F & P(perm) & $\begin{array}{c}\text { Unique } \\
\text { permutations }\end{array}$ \\
\hline \multirow{2}{*}{ Active } & Soil age & 3 & 10650 & 3550.2 & 2.2246 & $\mathbf{0 . 0 0 1}$ & 999 \\
& Residual & 11 & 17554 & 1595.8 & & & \\
& Total & 14 & 28205 & & & & 999 \\
Transition & Soil age & 3 & 9873.4 & 3291.1 & 1.9473 & $\mathbf{0 . 0 0 1}$ & \\
& Residual & 11 & 20281 & 1690.1 & & & \\
& Total & 14 & 30154 & & & & \\
& Soil age & 3 & 8186.2 & 2728.7 & 1.3886 & $\mathbf{0 . 0 4 3}$ & \\
& Residual & 11 & 19651 & 1965.1 & & & \\
& Total & 14 & 27837 & & & & \\
& & & & & & & \\
\end{tabular}

Significance is based on PERMANOVA.Active, transition, and frozen are different permafrost thawing status. 

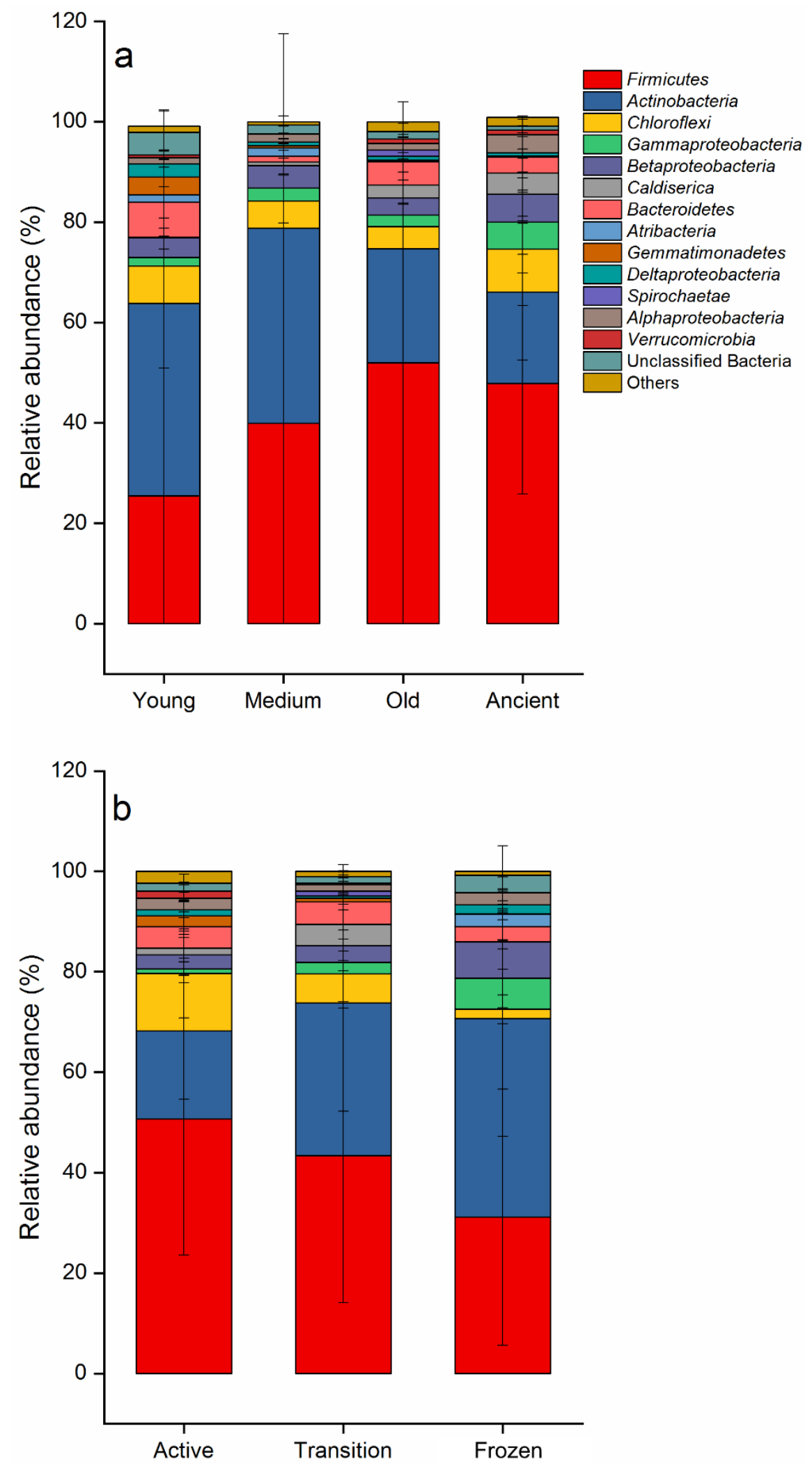

Fig. S1The relative abundance of the dominant bacteria with the permafrost age (a) and thawing status (b). Proteobacteria is at the class level. Young, medium, old, and ancient are permafrost soil ages, active, transition, and frozen are different permafrost thawing status. 
(a)
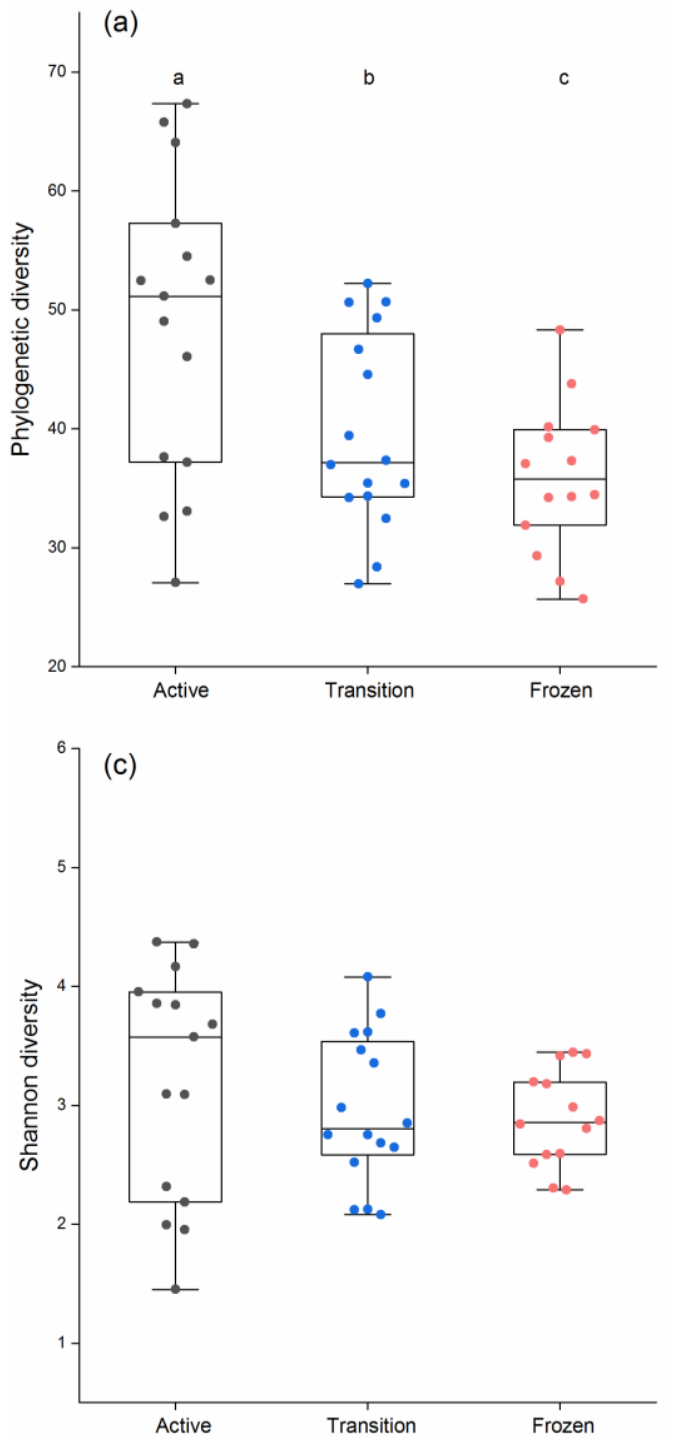

(b)

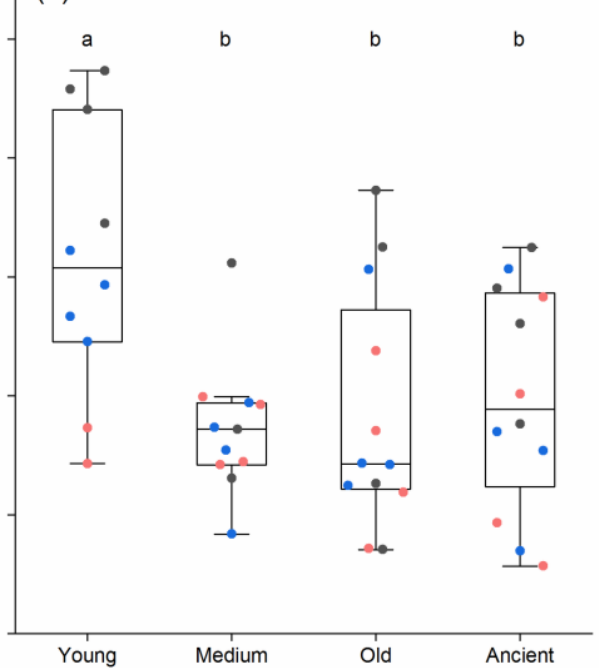

(d)

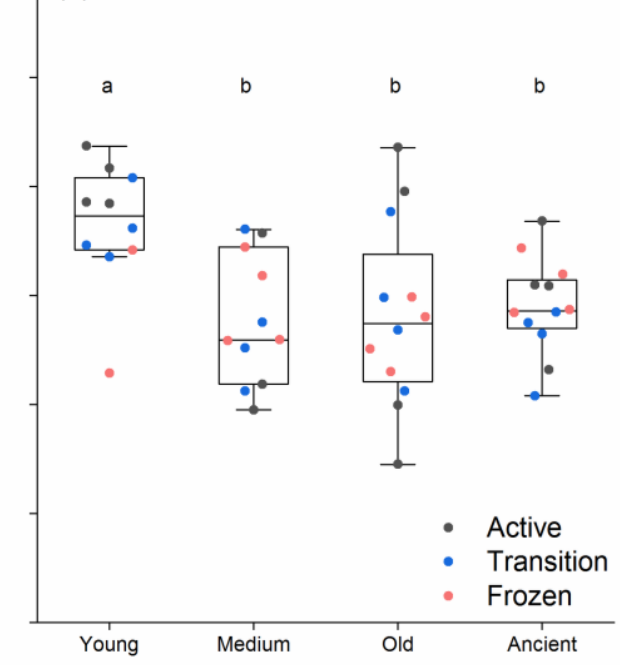

Fig. S2 Bacterial Phylogenetic diversity (a and b) and Shannon diversity (c and d) with the permafrost thawing status ( $\mathrm{a}$ and $\mathrm{c}$ ) and age ( $\mathrm{b}$ and d). Different letters indicate significant difference at $P<0.05$. Young, medium, old, and ancient are permafrost soil ages, active, transition, and permanently frozen are permafrost thawing statuses 


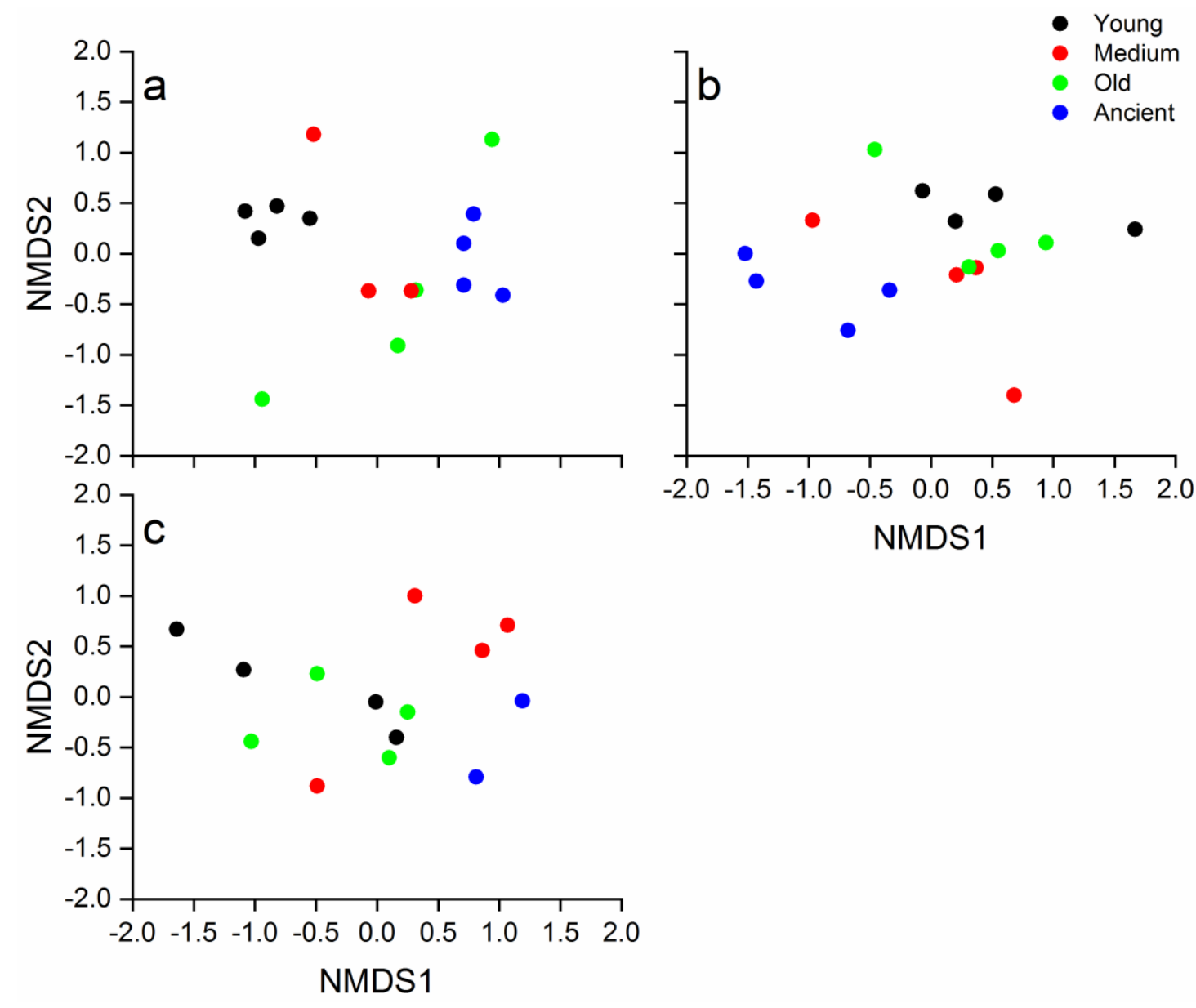

Fig. S3 NMDS ordination plot showing the community structure for permafrost soil bacteria with different permafrost ages but at the same thawing status. (a), the active layer of permafrost; (b), the transition layer of permafrost, and (c), the permanently frozen layer of the permafrost. Young, medium, old, and ancient are permafrost soil ages. 

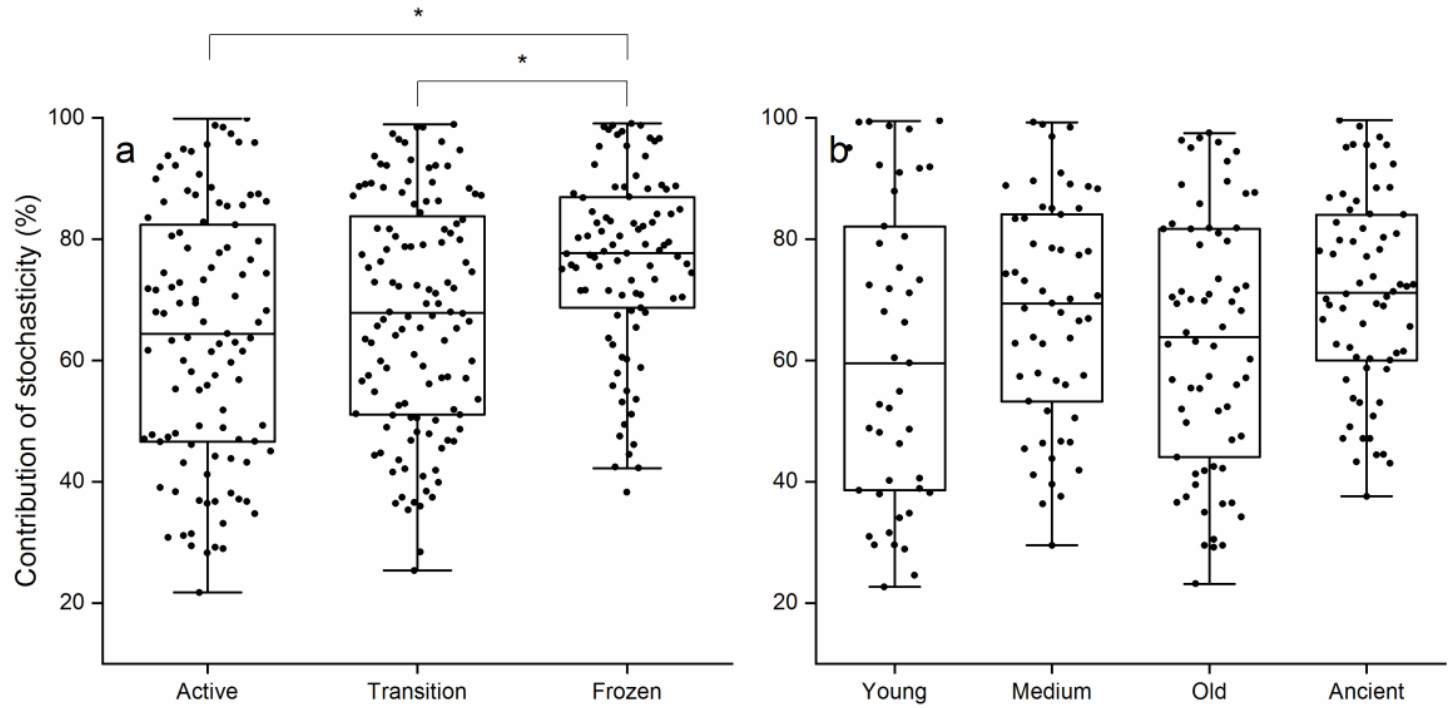

Fig. S4 Contribution of stochasticity on the bacterial community assembly for different permafrost thawing status (a) and soil ages (b). Contribution of stochasticity was based on the modified stochasticity index. * indicates significance at $P<0.05$. Young, medium, old, and ancient are permafrost soil ages. Active, transition, and frozen are different permafrost thawing status. 


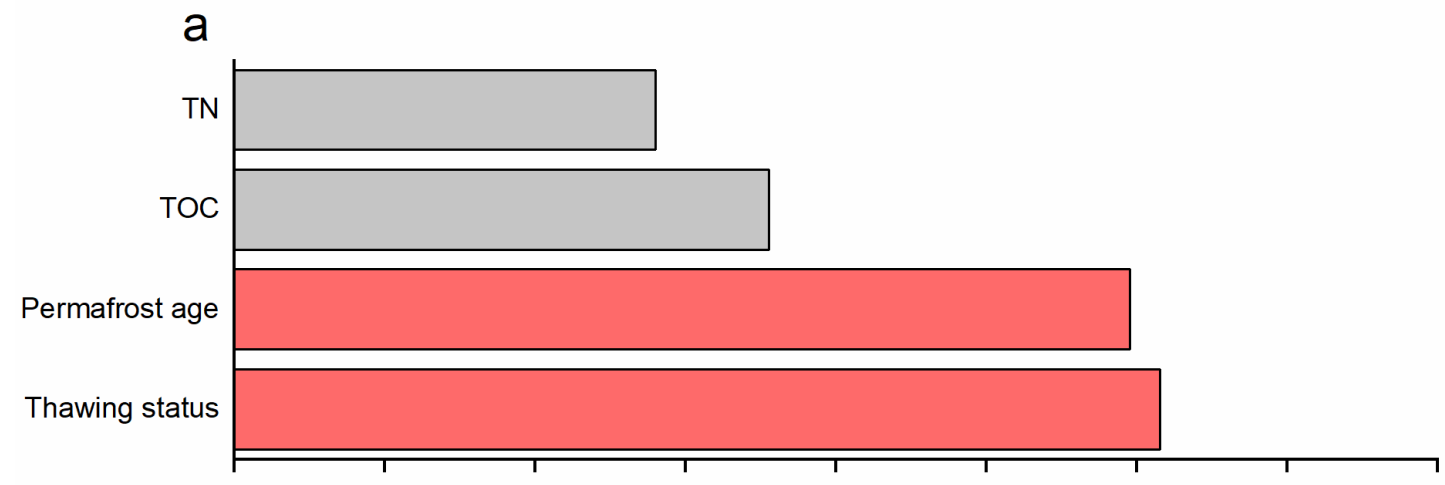

b
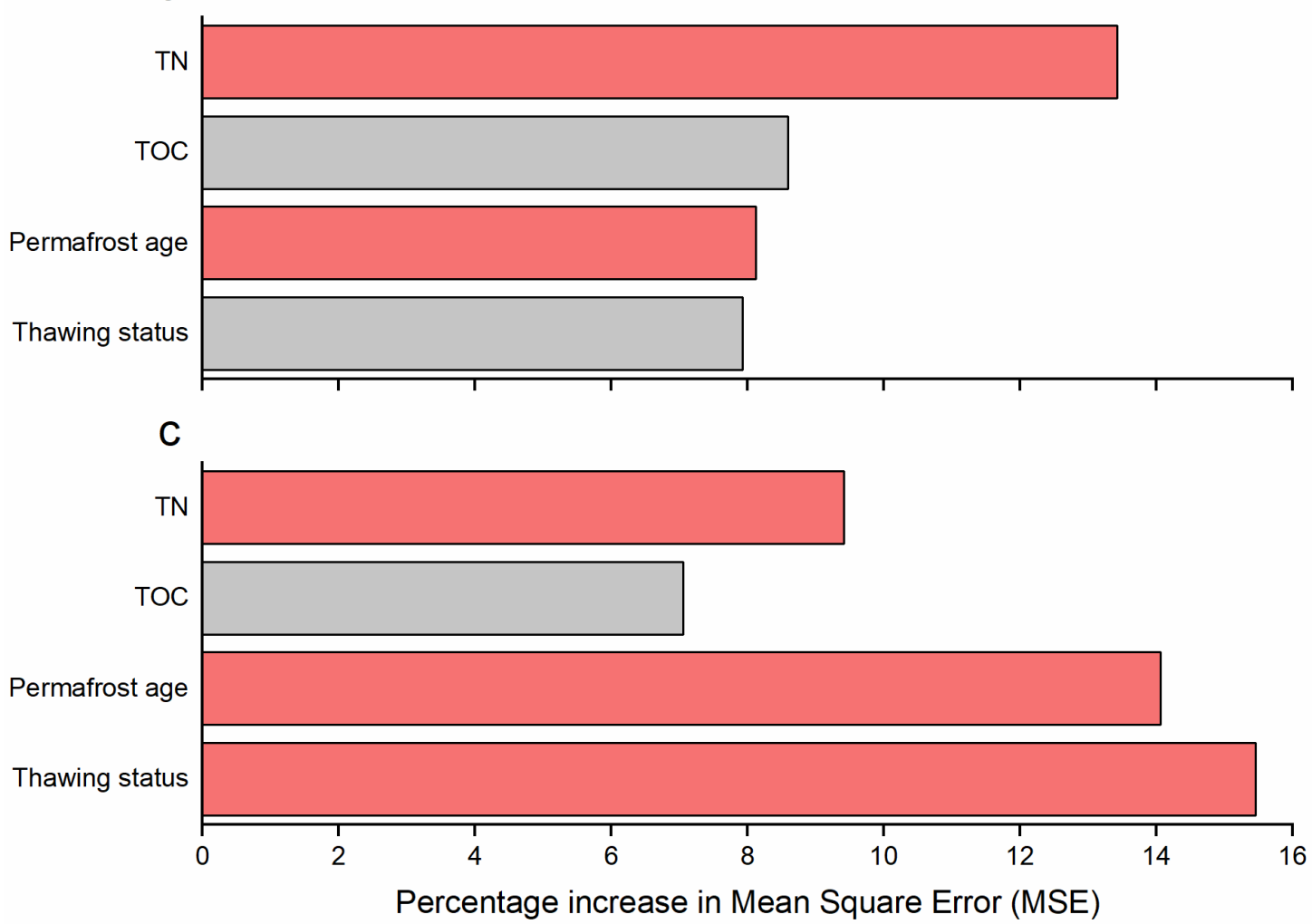

Fig. S5 Random Forest analysis results showing the contribution of permafrost age, thawing status, TOC and TN on the bacterial richness (a) and community structure. The community structure variation was assessed by the $1^{\text {st }}(\mathrm{b})$ and $2^{\text {nd }}$ (c) axis coordinates of the NMDS plot (NMDS1 and NMDS2). Significant contributions are in red, whereas non-significant contributions are in grey. 